\title{
ГЕНЕТИЧНЕ РІЗНОМАНІТТЯ ОСНОВНИХ ОЛІЙНИХ КУЛЬТУР УКРАЇНИ ЗА ЖИРНОКИСЛОТНИМ СКЛАДОМ ОЛІЇ
}

\author{
Тимчук Д. С., Харченко Л. Я.
}

\section{ВСТУП}

Рослинні олії $є$ необхідним компонентом харчового раціону людини i сировиною для виробництва продукції численних промислових виробництв, тому обсяги виробництва рослинних олій постійно зростають, а сфери використання олій - поширюються ${ }^{1}$.

Однак рослинні олії, які використовуються для досягнення різної мети, повинні вирізнятися різною сукупністю і споживчих властивостей, і технологічних показників, які найбільшою мірою відповідають специфічним вимогам конкретних сфер застосування олій.

Відомо, що основними ознаками, які визначають якість рослинних олій, є калорійність, жирнокислотний склад олії, а також вміст і склад жиророзчинних вітамінів, насамперед вітаміну $\mathrm{E}^{2}$. Однак відмінності між різними рослинними оліями за калорійністю малосуттєві ${ }^{3}$, а вміст і склад жиророзчинних вітамінів мають суттєве значення лише для олій харчового призначення, олій, що входять до складу кормів, та олій, що використовуються у фармацевтичній та парфумерно-косметичній галузях. Навпаки, жирнокислотний склад $є$ універсальним показником придатності олій для всіх сфер призначення, бо саме він зумовлює фізико-хімічні властивості гліцеридів, які є основним компонентом олій ${ }^{4}$.

За умови наявності ефективних технологій виділення олій та отримання 3 них широкого асортименту харчових, фармацевтичних та

${ }^{1}$ Industrial uses of vegetable oils : monograph / S.Z. Erhan Ed. Champaign, Ill.: AOCS Publ., 2005. 184 p. DOI: doi.org./10.4324/9781003040248; Mielke T. World markets of vegetable oils : status and prospects. Encyclopedia of sustainable science and technology series / R.A. Mayer Ed. New-York : Springer Sci., 2017. P. 261-298. DOI: doi.org/10.1007/978-1-4939-7813-7_989.

${ }^{2}$ Hammond E.W. Vegetable oils: types and properties. Encyclopedia of food sciences and nutrition / B. Caballero, P. Finglas, F. Toldra Eds. $2^{\text {nd }}$ ed. San-Diego ; London : Acad. Press, 2003. P. 5916-5921. DOI: 10.1016/B0-12-227055-X/01227-X.

${ }^{3}$ Oliveira L.E., Da Silva M.L.C.P. Comparative study of caloric value of rapeseed, soybean, jatropha and crambe biodiesel. Ren. Energ. Pow. Qual. J. 2013. V. 1 (11). P. 689-682. DOI: doi.org/10.24084/repqi11.411.

${ }^{4}$ McClements D.J., Decker E.A. Lipids. Fennema's food chemistry: monograph / S. Damodaran, K.L. Parkin, O.R. Fennema Eds. $4^{\text {th }}$ ed. Cpt. 5. Boca-Raton, Fl. : CRC Press, 2008. P. 155-216. DOI: 10.1016/j.foodchem.2012.04.040 
технічних продуктів, які застосовуються в сучасній олійно-жировій промисловості, дуже великого значення набуває іiі забезпечення високоякісною сировиною, пристосованою до конкретних галузей використання 5 .

Відомо, що різні олійні культури відмінні між собою за жирнокислотним складом олії, а деякі 3 них $€$ безпосередніми джерелами промислово цінних олій ${ }^{6}$.

Однак олійні культури 3 найбільш цінними оліями здебільшого потребують дуже специфічних грунтово-кліматичних умов вирощування, важко піддаються інтродукції, а отримувані з них олії для багатьох країн $є$ суто імпортованими продуктами, тому виникає необхідність створення промислових джерел високоякісних олій на основі культур, які пристосовані до вирощування в умовах країниспоживача й забезпечення таким чином своїх промислових виробництв власною олійною сировиною.

Найбільш доцільним, економічно вигідним і технічно здійснюваним способом вирішення цієї проблеми вважається генетичне поліпшення олійних культур за жирнокислотним складом ${ }^{7}$. Воно дає змогу отримувати високоякісні олії без додаткових фінансових та енергетичних витрат і зводить до мінімуму ризик екологічного забруднення довкілля, пов'язаний із заводськими технологіями переробки та збагачення. Окрім того, воно створює можливість виробництва різних за призначенням олій на основі однієї добре адаптованої до конкретної зони вирощування культури, що розширює діапазон іiі промислового використання та асортимент отримуваної продукції.

Однак практична реалізація цього напряму потребує уявлення про системи генетичної регуляції жирнокислотного складу олії різних культур, визначення його мінливості в різних умовах вирощування, виділення генетичних джерел покращеного жирнокислотного складу та їх практичного використання як вихідного матеріалу для селекції. Вирішення цих проблем $\epsilon$ необхідною умовою забезпечення результативності створення сортів та гібридів олійних культур.

${ }^{5}$ O'Brien R.D. Fats and oils: formulating and processing for applications : monograph. 3d ed., Boca-Raton, Fl. : CRC Press, 2008. 680 p. DOI: doi.org/10.1201/9781420061673.

${ }^{6}$ Arvanitoyannis I.S., Varzakas T.H., Kiokias S. Labropoulos A.E. Lipids, fats and oils. Advances in food biochemistry : monograph/ F. Vildiz Ed. Chpt. 5. Boca Raton, Fl. : CRC Press, 2010. P. 131-202. DOI: doi.org/10.1201/9781420007695.

${ }^{7}$ Kumara A., Sharmaa A., Upadhyayab K.C. Vegetable oils: nutritional and industrial perspective. Current Genomics. 2016. Is. 17. P. 230-240. DOI: 10.2174/1389202917666160202220107. 
Метою роботи $є$ узагальнення літературних даних і результатів досліджень генетичного різноманіття олійних культур України за жирнокислотним складом олії.

\section{1. Жирнокислотний склад рослинних олій і його регуляція}

\section{1. Структура і фізико-хімічні властивості жирних кислот рослинних олій}

Рослинні олії є сумішами речовин, що належать до різних класів ліпідних сполук, однак їх кількісно домінуючою фракцією $\epsilon$ гліцеринові ефіри вищих карбонових кислот. Оскільки спиртовий компонент усіх гліцеридів тотожний, їх фізико-хімічні властивості зумовлені складом, співвідношенням і положенням ацилів жирних кислот, що замикають складноефірні зв'язки .

Жирнокислотний склад гліцеридів олійних культур України у якісному відношенні $\epsilon$ досить поліморфним. Він представлений одноосновними карбоновими кислотами 3 нерозгалуженим скелетом i різною, як правило, парною кількістю вуглецевих атомів $\left(\mathrm{C}_{12}-\mathrm{C}_{24}\right)$, а також різною кількістю подвійних зв'язків у молекулі (1-3). У складі деяких олій зустрічаються оксикислоти'.

Фізико- хімічні й біологічні властивості олій залежать як від довжини вуглецевого скелету жирних кислот, що входять до складу гліцеридів, так і від кількості дієнових зв'язків у їх молекулах. Так, за повної відсутності чи однакової кількості дієнових зв'язків зі збільшенням довжини вуглецевого скелету зростає температура плавлення кислоти та іiї ефірів. Навпаки, у кислот із рівною довжиною вуглецевого скелету за збільшення кількості дієнових зв'язків температура плавлення знижується ${ }^{10}$.

Показано, що жирнокислотний склад олії є вирішальним фактором, який визначає фізичні властивості олій, зокрема в'язкість, реологічні властивості, а також термостабільність ${ }^{11}$.

${ }^{8}$ Valenzuela Baez R., Valenzuela Baez A. Overview about lipid structure. Lipid metabolism : monograph / R. Valenzuela Ed. Chpt.1. Rijeka,Croatia : InTech, 2013. P. 3-20. DOI : 10.5772/52306.

${ }^{9}$ Rustan A.C., Drevon C.A. Fatty Acids: structures and properties. Encyclopedia of Life Sciences. Chichester : John Wiley \& Sons, Ltd., Chichester, 2005. V. 7. P. 1-7. DOI: doi.org/10.1038/npg.els.0003894.

${ }^{10}$ Cnothe G., Dunn R.O. A comprehensive evaluation of the melting points of fatty acids and esters determined by differential scanning calorimetry. J. Amer. Oil Chem. Soc. 2009. V. 86 (9). P. 843-856. DOI: 10.1007/s11746-009-1423-2.

${ }_{11}$ Devi A., Khatkar B.S. Physicochemical, rheological and functional properties of fats and oils in relation to cookie quality: a review. J. Food Sci. Technol. 2016. V. 53 (10). P. 3633-3641. DOI: 10.1007/s 13197-016-2355-0. 
Хімічні й біологічні властивості олій теж залежать від їх жирнокислотного складу, насамперед від кількості дієнових зв'язків у жирних кислот, що входять до складу гліцеридів ${ }^{12}$.

Насичені кислоти в структурі молекули подвійних зв'язків не мають, їх обмінна активність мінімальна, тому вони виконують функції енергетичних донорів і, можливо, ацил-переносників.

Навпаки, ненасичені кислоти беруть активну участь у обмінних процесах. Антисклеротичні властивості ненасичених кислот, що пов'язані з виведенням з організму холестерину, настільки великі, що їх функція до останнього часу розглядалась як $\mathrm{F}$-вітамінна ${ }^{13}$. В рослинних оліях ця функція притаманна двом кислотам, а саме линолевій i линоленовій, хоча маються відомості, що за F-вітамінною активністю линоленова кислота значно поступається линолевій. Моноєнова олеїнова кислота не має фізіологічної активності линолевої, але фізіологічний ефект останньої може синергічно підсилюватися олеатом.

Всі полієнові кислоти, зокрема линолева і линоленова, не можуть синтезуватися організмами людини та тварин, є незамінними, a їх виключним джерелом $є$ продукти рослинного походження.

Саме у високому вмісті гліцеридів ненасичених кислот полягають переваги рослинних олій перед тваринними жирами. Однак переважання у складі рослинних олій ненасичених карбонових кислот має небажаний біохімічний ефект. Атоми водню в радикалах, що замикають дієнові зв'язки, вирізняються високою реакційною здатністю, а під час взаємодії ацилів ненасичених жирних кислот із молекулярним киснем виникає ланцюгова реакція утворення токсичних оксидів та пероксидів 3 дуже небажаним фізіологічним ефектом ${ }^{14}$.

Інтенсивність окислення залежить насамперед від жирнокислотного складу олії. Із збільшенням ступеня ненасиченості карбонових кислот, що входять до складу олій, швидкість їх автоокислювання зростає. Зокрема, за інтенсивністю автоокислювання дієнова линолева кислота

${ }^{12}$ White P. Fatty acids of oilseeds vegetable oils. Fatty acids in foods and their health implications : monograph / C.K. Chow Ed. 3d ed. Cpt. 10. Boca-Raton, Fl. : CRC Press, 2007. P. 227-262. DOI: doi.org/10.1201/9781420006902.ch.10.

${ }^{13}$ Ratledge C. Microbial production of vitamin F and other polyunsaturated fatty acids. Industrial biotechnology of vitamins, biopigments and antioxidants : monograph / E.J. Vandamme, J.L. Revuelta Eds. $3^{\text {th }}$ ed. Chpt. 11. Weinheim : Wiley VCH, 2016. P. 287-320. DOI: 10.1002/9783527681754.ch11.

${ }^{14}$ Niki E., Yoshida Y., Saito Y., Noguchi N. Lipid peroxidation: mechanisms, inhibition, and biological effects. Biochim. Biophys. Res. Commun. 2005. V. 338 (1). P. 668-676. DOI: 10.1016/j.bbrc.2005.08.072. 
значно перевищує моноєнову олеїнову, а триєнова линоленова линолеву ${ }^{15}$.

Отже, олії 3 високим вмістом гліцеридів насичених і мононенасичених кислот, принаймні олеїнової, вирізняються більш високою стійкістю до перекисного окислювання ліпідів, ніж олії, у складі яких переважають поліненасичені кислоти. Однак F-вітамінна активність у олій поліненасиченого типу вище.

Отримані результати свідчать про те, що олії 3 різним жирнокислотним складом дуже відмінні між собою за фізикохімічними властивостями, тому поліпшення жирнокислотного складу може розглядатися як перспективний спосіб створення промислових джерел високоякісної сировини для виробництв, у яких використовуються рослинні олії.

\section{2. Біохімічні механізми утворення жирних кислот}

Результативні рішення підвищення якості олії неможливі без розуміння процесу біосинтезу жирних кислот.

На підставі аналізу спеціальної літератури ${ }^{16}$ i результатів власних досліджень цей процес можна представити такою схемою (рис. 1).

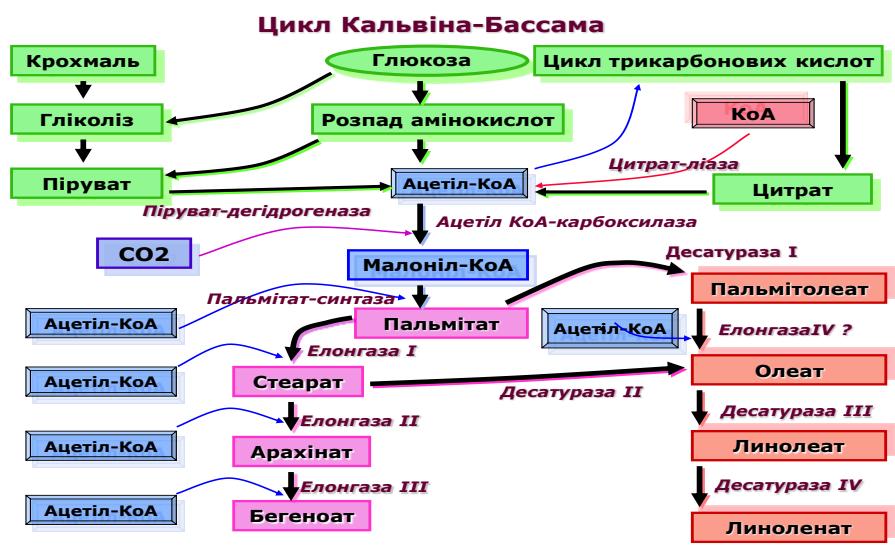

Рис. 1. Принципова схема процесу утворення жирних кислот у вищих рослин

${ }^{15}$ McClements D.J., Decker E.A. Lipids. Fennema's food chemistry : monograph / S. Damodaran, K.L. Parkin, O.R. Fennema Eds. $4^{\text {th }}$ ed. Cpt. 5. Boca-Raton, Fl. : CRC Press, 2008. P. 155-216. DOI: 10.1016/j.foodchem.2012.04.040.

16 Vanhercke T., Wood C.C., Stymne S., Singh S.P., Green A.G. Metabolic engineering of plant oils and waxes for use as industrial feedstocks. Plant Biotechnol. J. 2013. V. 11 (2). P. 197-210. DOI: 10.1111/pbi.12023. 
Згідно $з$ цією дуже спрощеною схемою, першою серед жирних кислот утворюється пальмітинова, а всі подальші процеси утворення жирних кислот здійснюються в ході двох сполучених процесів, а саме подовження вуглецевого скелету i десатурації насичених зв'язків. Перший з цих процесів каталізується специфічними елонгазами, які подовжують вуглецевий ланцюг, а другий - десатуразами, які перетворюють насичені зв'язки на ненасичені.

Утворення насичених жирних кислот $\mathrm{C}_{18}-\mathrm{C}_{22}$ визнається результатом послідовної ступінчастої елонгації, за якої стеарат $\left(\mathrm{C}_{18}\right)$ утворюється $з$ пальмітату $\left(\mathrm{C}_{16}\right)$, арахінат $\left(\mathrm{C}_{20}\right)$ - iз стеарату, а бегеноат $\left(\mathrm{C}_{22}\right)$ - iз арахінату.

Ненасичені кислоти можуть утворюватися як із насичених, так і 3 ненасичених, але 3 меншою кількістю дієнових зв'язків. При цьому перетворення насичених зв'язків на ненасичені здійснюється ступінчасто, а в ході кожної реакції відбувається десатурація тільки одного насиченого зв'язку, як правило, починаючи $3 \mathrm{C}_{9}-\mathrm{C}_{10}$, тому утворення жирних кислот з різним ступенем ненасиченості каталізується не однією, а кількома десатуразами, причому специфічність кожної з них визначається положенням атакованого зв'язку.

Загалом отримані результати свідчать про те, що біохімічний механізм утворення та взаємоперетворення жирних кислот має універсальний і консервативний характер. Хоча кожна олійна культура має свою специфіку синтезу жирних кислот, а деякі жирні кислоти зустрічаються тільки у представників певних ботанічних видів, основні реакції цього процесу і ферменти, які їх каталізують, у різних олійних культур схожі.

Ця особливість дає можливість розробити загальну технологію генетичного поліпшення жирнокислотного складу олії та створення на цій основі корисного генетичного різноманіття за якістю олії.

\section{3. Генетична регуляція жирнокислотного складу гліцеридів}

Найбільш результативним та економічно вигідним способом досягнення бажаного жирнокислотного складу олії вважається генетичне поліпшення, а необхідною передумовою для нього $\epsilon$ встановлення генетичних детермінантів ознаки ${ }^{17}$. Сам факт їх існування сумнівів не викликає та експериментально підтверджений численними експериментальними результатами. Однак конкретні оцінки цих детермінантів досить обмежені й суперечливі.

${ }^{17}$ Vollmann J., Raican I. Oil crop breeding and genetics. Oil crops : monograph / J. Volmann, I. Raican Eds. Chpt. 1. Dordrecht ; Heidelberg ; London ; New-York : Springer Sci., 2009. P. 1-30. DOI: 10.1007/978-0-387-77594-4_1. 
Ідентифікацію генетичних детермінантів жирнокислотного складу дуже ускладнює значна залежність фенотипу від грунтово-кліматичних умов вирощування ${ }^{18}$. Водночас виявлення й використання генетичних факторів, які регулюють вміст окремих жирних кислот та їх сукупності, дало змогу вже на цей час отримати форми олійних культур із суттєво поліпшеною якістю олій ${ }^{19}$.

Технології генетичного перерозподілу жирнокислотного складу олії грунтуються на визнанні того факту, що регуляція синтезу жирних кислот визначається насамперед інтенсивністю його каталізу. Основна відмінність між ефектами звичайних та мутантних алелів генів, що контролюють синтез жирних кислот, полягає в регуляціїі утворення ними активних або пасивних ізоформ ферментів зі схожою субстратною специфічністю.

Під час поліпшення жирнокислотного складу найчастіше використовується ефект мутантних генів FAD2 i FAD3, які

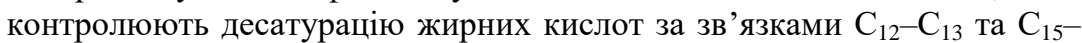
$\mathrm{C}_{16}{ }^{20}$. Окрім того, для генетичного поліпшення деяких олійних культур використовується ефект мутантного гену FAD1, який каталізує десатурацію зв'язку $\mathrm{C}_{9}-\mathrm{C}_{10}$ і двох генів ELO1 та ELO2, які регулюють активність елонгаз ${ }^{21}$.

Отримання мутацій олійних культур 3 корисним ефектом за жирнокислотним складом олії, як правило, здійснюється шляхом хімічного мутагенезу або трансгенезу ${ }^{22}$. Обидва ці способи не полишені своїх певних недоліків.

${ }^{18}$ Aguirrezabal L., Martre P., Pereyra-Irujo G., Izquerdo N., Allard V. Management and breeding strategies for the improvement of grain and oil quality. Crop physiology: application for genetic improvement and agronomy : monograph / V.O. Sardas, D.F. Calderini Eds. Chpt. 16. Burlington, MA : Elsevier-Academic Press, 2009. P. 387421. DOI: doi.org/10.1016/B978-0-12-374431-9.00016-5.

${ }^{19}$ Dyer J.M., Mullen R.T. Development and potential of genetically engineered oilseeds. Seed Science Research. 2005 V. 15 (4). P. 255-267. DOI: 10.1079/SSR2005216.

${ }^{20}$ Vritten P., Hu Z., Muchinsky M.-A., Rowland G., Qui X. Two FAD3 desaturase genes control the level of linolenic acid in flax seed. Plant Physiol. 2005.V. 139.P. 79-87. DOI: 10.1104/pp.105.064451; Dar A.A., Choudhury A.R., Kancharla P.K., Arumugam N. The FAD2 gene in plants: occurrence, regulation and role. Front. Plant Sci. 2017. Is. 8. Article 1789. 16 p. DOI: 10.3389/fpls.2017.01789.

${ }^{21}$ Pandjabi P., Yadava S.K., Kumar N., Bangkim R., Ramchiary N. Breeding Brassica juncea and B.rapa for sustainable oilseed production in the changing climate: progress and prospects. Genomic designing of climate - smart oilseed crops : monograph / C. Kole Ed. Chpt. 6. Cham, SWI : Springer, 2019. P. 275-369. DOI: 10.1007/978-3-319-93536-2_6.

${ }_{22}$ Murphy D.J. Using modern plant breeding to improve the nutritional and technological qualities of oil crops. Oiseeds \& Fats Crops Lipids. 2014. V. 21 (6). D. 607. DOI: $10.1051 / \mathrm{ocl} / 2014038$. 
Хімічний мутагенез, як правило, має спорадичний характер i викликає мутування не конкретного локусу, а всієї його групи зчеплення, тому отримання корисної мутацій під час його застосування супроводжується появою серії інших мутацій, часто 3 небажаним ефектом. Однак останнім часом вдалося розробити технології індукції точкових мутацій, які підвищують результативність створення генетичного різноманіття за жирнокислотним складом олії ${ }^{23}$. Трансгенні технології, незважаючи на свою результативність, викликають непрогнозовані екологічні наслідки, які можуть бути як корисними, так і шкідливими.

3 цього погляду було б дуже перспективним виділення джерел покращеного жирнокислотного складу олії серед природного генетичного різноманіття олійних культур. Результати його оцінок свідчать про те, що ці культури вирізняються дуже широким різноманіттям за жирнокислотним складом олії, використання якого дає змогу ефективно вирішувати проблеми селекційно-генетичного підвищення якості олій ${ }^{24}$.

В Україні, як і багатьох інших країнах, зосереджено значне генетичне різноманіття олійних культур i виникає необхідність узагальнення його багаторічних оцінок за жирнокислотним складом олії.

\section{2. Матеріал і методика досліджень}

Об'єктами досліджень були представлені вибірки ліній, сортів та гібридів олійних культур, що є основними об'єктами національної селекції, а саме кукурудзи (Zea mays L.), соняшнику (Helianthus annuus L.), coї (Glycine max Merr.), культур родини Капустяних (Brassicaceae), а саме ріпаку (Brassica napus L.), суріпиці (Brassica campestris L.) та гірчиці (Sinapis alba L., Brassica juncea L.) 3 колекцій Устимівської дослідної станції рослинництва.

До досліджень було залучено також лінії кукурудзи - носії мутантних генів структури ендосперму $s u_{1}, a e, s u_{2}$ та $w x$, які, за попередніми даними, можуть бути зчеплені з найбільш експресивними

${ }^{23}$ Haun W., Coffman A., Clasen B.M., Demorest Z.L., Lowy A., Ray E., Retterath A., Stoddart T., Juilletat A., Cedrone F., Mathis L., Voytas D.F., Zhang F. Improved soybean oil quality by targeted mutagenesis of the fatty acid desaturase 2 gene family. Plant Biotechnol. J. 2014. V. 12 (7). P. 934-940. DOI: 10.1111/pbi.12201.

${ }^{24}$ Gavrilova V., Shelenga T., Porokhovinova E., Dubovskaya A., Kon'kova N., Grigoryev S., Podolnaya L., Konarev A., Yakusheva T., Kishlyan N., Pavlov A., Brutch N. The diversity of fatty acid composition in traditional and rare oil crops cultivated in Russia. Bio. Comm. 2020. № 65 (1). P. 68-81. DOI: doi.org/10.21638/spbu03.2020.106. 
олеат- та пальмітат-кодуючими локусами, розташованими в 4, 5, 6 та 9 хромосомах $^{25}$.

Жирнокислотний склад олї аналізували модифікованим газохроматографічним методом Пейскера ${ }^{26}$.

\section{3. Генетичне різноманіття олійних культур України за жирнокислотним складом}

\section{1. Кукурудза (Zea mays L.)}

Кукурудза не належить до числа провідних олійних культур, однак iii олія вдало поєднує F-вітаминну та антиоксидантну активність і вважається однією 3 найкращих олій харчового призначення ${ }^{27}$. Окрім того, кукурудза серед культурних рослин має чи не найширші ареал розповсюдження i діапазон багатоцільового промислового використання товарної продукції.

Основним напрямом підвищення якості кукурудзяної олії є підвищення вмісту в ній гліцеридів олеїнової кислоти 3 використанням для цього ефекту мутантних генів, які знижують активність десатураз fad2 та fad6 та інтенсивність конверсії олеату в линолеат ${ }^{28}$.

Основна складність ідентифікації мутацій кукурудзи 3 корисним ефектом за вмістом олеату полягає у відсутності їх візуально діагностованих маркерів та необхідності застосування досить складних молекулярно-генетичних методів або оцінок за фенотипом, тому уявляється перспективним використання для цього носіїв таких мутацій, які просторово зчеплені з олеат-кодуючими локусами і мають візуально діагностовані фенотипи. До них слід віднести насамперед мутації структури ендосперму ${ }^{29}$.

${ }^{25}$ Yang X., Guo Y., Yan J., Zhang J., Song T., Rocheford T., Li J.-S. Major and minor QTL and epistasis contribute to fatty acid compositions and oil concentration in high-oil maize. Theor. Appl. Genet. 2010. V. 120 (3). P. 665-678. DOI: 10.1007/s00122-009-1184-1.

${ }^{26}$ Прохорова М.И. Методы биохимических исследований. Ленинград : Химия, 1982. 272 c.

27 Wang T., White P. Lipids of the kernel. Corn: chemistry and technology : monography / S.O. Serna-Saldivar Ed. 3th Ed. Chpt. 13. Duxford, UK : ElsevierWoodhead Publ., 2019. P. 337-368. DOI: https://doi.org/10.1016/b978-0-12-8119716.00013-9.

${ }^{28}$ Singh N., Vasudev S., Yadava D.K., Chaudhary D.P., Prabhu K.V. Oil improvement in maize : potential and prospects. Maize: nutrition dynamics and novel uses : monography / D.P. Chaudhary, S. Kumar, S. Langyan Eds. Chpt. 6. Heidelberg ; New-York ; Dordrecht ; London : Springer, 2014. P. 77-82. DOI: 10.1007/978-81-322-1623-0_6.

${ }^{29}$ Boyer C.D., Hannah L.C. Kernel mutants of corn. Specialty corns : monograph $/$ A.R. Hallauer Ed. Boca Raton, Fl. : CRC Press, 2001. P. 8-38. DOI: doi.org/10.1201/9781420038569. 
Результати проведених досліджень показали, що вміст олеату в кукурудзяній олії має полігенну природу, а найбільш експресивні олеат-кодуючі локуси розташовані в 4,5 i 6 хромосомах $^{30}$, де локалізовано гени структури ендосперму $s u_{1}$, ae та $s u_{2}{ }^{31}$.

$€$ відомості, що в 9 хромосомі мається локус, який контролює у кукурудзи підвищений вміст пальмітинової кислоти ${ }^{32}$ і який може бути просторово зчеплений з геном структури ендосперму $w x$.

Отже, в наших дослідах було зроблено спробу оцінити жирнокислотний склад олії неспоріднених за походженням ліній звичайного типу і ліній-носіїв ендоспермових мутацій $s u_{1}$, $a e, s u_{2}$ та $w x$ задля визначення їх практичної значушості для розширення корисного генетичного різноманіття за якістю олії.

Встановлено, що найбільш мінливими компонентами жирнокислотного складу олій у всіх груп ліній є пальмітинова, олеїнова та линолева кислоти (табл. 1).

Таблиця 1

Мінливість вмісту гліцеридів пальмітинової (C16:0), олеїнової (C18:1) та линолевої (C18:2) кислот в оліях ліній кукурудзи звичайного типу і ліній-носіїв ендоспермових мутацій, результати дворічних оцінок

\begin{tabular}{|c|c|c|c|c|c|c|}
\hline \multirow{2}{*}{ Типи ліній } & \multicolumn{3}{|c|}{ Вміст гліцеридів жирних кислот, \% до суми } \\
\cline { 2 - 7 } & Мін.-макс. & Середнє & Мін.-макс. & Середнє & $\begin{array}{c}\text { Мін.- } \\
\text { мак. }\end{array}$ & Середнє \\
\hline Звичайний & $8,3-12,9$ & 10,6 & $18,2-29,8$ & 26,4 & $54,4-63,7$ & 57,2 \\
\hline Носії мутації $s u_{1}$ & $8,9-11,2$ & 9,8 & $39,7-44,3$ & 41,6 & $43,1-46,6$ & 44,5 \\
\hline Носії мутації $a e$ & $9,5-12,1$ & 11,2 & $29,7-34,5$ & 30,9 & $47,8-55,2$ & 53,6 \\
\hline Носії мутації $s u_{2}$ & $9,3-11,4$ & 10,1 & $34,3-37,2$ & 36,7 & $47,3-52,5$ & 49,1 \\
\hline Носії мутації $w x$ & $11,8-14,2$ & 12,6 & $24,3-27,4$ & 25,9 & $53,3-58,7$ & 56,8 \\
\hline НІР $_{0,05}$ & & 0,8 & & 1,1 & & 1,4 \\
\hline
\end{tabular}

${ }^{30}$ Mikkilineni V., Rocheford T.R. Sequence variation and genomic organization of fatty acid desaturase-2 (fad2) and fatty acid desaturase-6 (fad6) cDNAs in maize. Theor. Appl. Genet. 2003. V. 106 (7). P. 1326-1332. DOI: 10.1007/s00122-003-1190-7; Belo A., Zheng P., Luck S., Shen B., Meyer D.J., Li B., Tingey S., Rafalski A. Whole genome scan detects an allelic variant of fad 2 associated with increased oleic acid levels in maize. Mol. Genet. Genom. 2008. № 279 (1). P. 1-10. DOI: 10.1007/s00438-007-0289-y; Wassom J.J., Mikkilineni V., Bohn M.O., Rocheford T.R. QTL for fatty acid composition of maize kernel oil in Illinois High Oil $\times$ B73 backcross-derived lines. Crop Sci. 2008. № 48 (1). P. 69-78. DOI: doi.org/10.2135/cropsci2007.040208.

31 Coe E.H., Schaeffer M.L. Genetic, physical, maps, and database resources for maize. Maydica, 2005 . № $50 \quad$ (3). $\quad$ P. 285-303. DOI: doi.org/10.1371/journal.pgen.0030123.

${ }^{32}$ Yang X., Guo Y., Yan J., Zhang J., Song T., Rocheford T., Li J.-S. Major and minor QTL and epistasis contribute to fatty acid compositions and oil concentration in high-oil maize. Theor. Appl. Genet. 2010. V. 120 (3). P. 665-678. DOI: 10.1007/s00122-0091184-1. 
Отримані результати свідчать про те, що за вмістом олеату носії мутації $s u_{1}$ перевищують звичайну кукурудзу в середньому на $57,8 \%$, носії мутації $a e-$ на $17,1 \%$, а носії мутації $s u_{2}-$ на $39,0 \%$. Водночас лінії-носії мутації $w x$ перевищували лінії звичайного типу та лінії на основі інших мутацій за вмістом пальмітату. Порівняно 3 лініями звичайного типу це перевищення становило в середньому $18,9 \%$.

Результати проведених оцінок показали, що вміст пальмітату, олеату та линолеату у неспоріднених ліній на основі однієї мутації варіював. Це, скоріше за все, пов'язано з тим, що регуляція цих ознак не $€$ моногенною, алелі олеат- або пальмітат-кодуючих локусів, не зчеплених 3 локусами структури ендосперму, можуть вільно комбінуватися, що викликає кількісну мінливість вмісту зазначених компонентів жирнокислотного складу олій.

Нині показано можливості підвищення вмісту олеату та пальмітату в олії кукурудзи шляхом використання екзотичних джерел цих ознак ${ }^{33}$. Як інші поки що не використовувані джерела покращеного жирнокислотного складу олії можна розглядати носіїв ендоспермових мутацій.

\section{2. Соняшник (Helianthus annuus L.)}

Соняшник $є$ однією з провідних олійних культур світу і провідною олійною культурою України, олія якого широко використовується для харчових та технічних потреб. Хоча ця культура не дуже добре картована, нині у неї досить повно досліджено системи генетичної регуляції жирнокислотного складу олії і створено широке різноманіття за вмістом практично всіх його компонентів ${ }^{34}$.

Найбільш популярним напрямом у селекції соняшнику на якість олії $\epsilon$ підвищення вмісту олеїнової кислоти. Існують значні розбіжності в оцінках природи генетичних факторів, які контролюють цей феномен. Однак останні результати свідчать про те, що високий вміст олеїнової кислоти в оліях соняшнику має домінантну природу і контролюється кількома комплементарними генами ${ }^{35}$.

${ }^{33}$ White P.J., Pollak L.M., Duvick S. Improving the fatty acid composition of corn oil by using germplasm introgression. Lipid Technol. 2007. V. 19 (2). P. 35-38. DOI: doi.org/10.1002/lite.200600009.

${ }^{34}$ Scoric D., Seiler G., Liu Z., Jan C.-C., Miller J.F., Charlet L.D. Sunflower genetics and breeding. International monography. Novi Sad : Serbian Acad. Sci.Art. 2012. 520 p. DOI: $10.3390 /$ genes 9110528 .

${ }^{35}$ Ferfuia C., Vannozzi G.P. Maternal effect on seed fatty acid composition in a reciprocal cross of high oleic sunflower (Helianthus annuus L.). Euphytica. 2015. V. 205 (2). P. 325-336. DOI: 10.1007/s10681-015-1378-3. 
Встановлено, що вміст пальмітинової та стеаринової кислот регулюється рецесивними алелями ${ }^{36}$.

Повідомлялося про ідентифікацію принципово нового мутанту соняшнику, олія якого містить до $12 \%$ пальмітолеїнової кислоти (С 16:1), до $5 \%$ пальмітлинолевої кислоти (С 16:2) i до $6 \%$ просторового ізомеру олеїнової кислоти, в якому дієновий зв'язок розташовано між 11 та 12 атомами вуглецевого скелету ${ }^{37}$.

Такі детальні й практично значущі дослідження привели до створення широкого генетичного різноманіття соняшнику за жирнокислотним складом олії. На цій основі сформовано чотири типи соняшнику (табл. 2).

Таблиця 2

Жирнокислотний склад олії представників основних типів соняшнику, сформованих на основі генетичного різноманіття культури, зосередженого в Україні ${ }^{38}$

\begin{tabular}{|c|c|c|c|c|c|}
\hline \multirow{2}{*}{$\begin{array}{c}\text { Тип жирнокислотного } \\
\text { складу олії }\end{array}$} & \multicolumn{5}{|c|}{ Вміст гліцеридів жирних кислот, \% до суми } \\
\cline { 2 - 6 } & $\mathbf{C 1 6 : 0}$ & $\mathbf{C 1 6 : 1}$ & $\mathbf{C 1 8 : 0}$ & $\mathbf{C 1 8 : 1}$ & $\mathbf{C 1 8 : 2}$ \\
\hline Звичайний & 7,5 & 0,2 & 3,4 & 26,6 & 58,4 \\
\hline Пальмітиновий & 39,6 & 7,3 & 3,7 & 12,2 & 35,0 \\
\hline Стеариновий & 7,3 & 1,0 & 11,0 & 21,7 & 58,9 \\
\hline Олеїновий & 3,7 & 0,1 & 2,7 & 90,5 & 2,3 \\
\hline Линолевий & 3,4 & 0,7 & 2,0 & 12,2 & 81,7 \\
\hline
\end{tabular}

\section{3. Соя (Glycine max Merr.)}

За рівнем валового виробництва соя $є$ провідною олійною культурою світу, ії олія активно використовується як харчовий продукт i сировина для численних промислових виробництв. Соєва олія вирізняється високим вмістом токоферолів і ненасичених жирних кислот, що забезпечує іï високу біологічну цінність, а основним

${ }^{36}$ Perez-Vich B., Fernandez J., Garces R., Fernandez-Martinez J.M. Inheritance of high palmitic acid content in the seed oil of sunflower mutant CAS-5. Theor. Appl. Genet. 1999. V. 98. P. 496-501. DOI: 10.1007/s001220051097; Perez-Vich B., Garces R., Fernandez-Martinez J.M. Genetic control of high stearic acid content in the seed oil of sunflower mutant CAS-3. Theor.Appl.Genet. 1999. V. 99 (3-4). P. 663-669. DOI: doi.org/10.1007/s001220051282.

${ }^{37}$ Salas J.J., Martinez-Force E., Garces R. Biochemical characterization of a highpalmitoleic acid Helianthus annuus mutant. Plant Physiol.Biochem. 2004. V. 42 (5). P. 373-381. DOI: 10.1016/j.plaphy.2004.03.001.

38 Кириченко В.В., Тимчук С.М., Брагін О.М. Генетичне різноманіття ліній соняшнику за жирнокислотним складом олії. Генетичні ресурси рослин. 2007. № 4. C. 131-139. 
недоліком соєвої олії є підвищений вміст ліноленової кислоти ${ }^{39}$. Він не настільки високий, щоб розглядати цю олію як технічну, і занадто високий для олій харчового призначення. Соєва олія дуже схильна до перекисного окислювання, тому зниження вмісту ліноленової кислоти $€$ основним напрямом генетичного поліпшення сої ${ }^{40}$. Окрім того, у сої, як i y інших культур, практично значущими $є$ як підвищення, так i зниження вмісту насичених кислот і підвищення олеїнової ${ }^{41}$.

Нині відомо, що вміст пальмітинової кислоти у сої має кількісну природу й контролюється множинними аллелями серії fap, вміст стеаринової - алелями серії $f a s$, вміст олеїнової - алелями серії Fad, а вміст ліноленової - алелями серії $f a n^{42}$. Ефекти цих алелей та їх комбінацій становили предмет численних досліджень, внаслідок яких було отримано практично значущі джерела олій 3 покращеним жирнокислотним складом, зокрема нетрадиційним ${ }^{43}$.

В Україні селекція сої на якість олії ще не отримала потрібного розвитку, оскільки соєва олія на внутрішньому ринку за попитом поступається соняшниковій. Однак у селекційно-генетичних установах України зосереджено досить широке генетичне різноманіття сої за жирнокислотним складом олії.

Його узагальнення дає змогу виділити групи спеціалізованих сортів сої зі специфічним для кожної групи жирнокислотним складом. Характеристику представників кожної групи наведено у табл. 3.

39 O'Brien R.D. Soybean oil modification. Soybeans: chemistry, production, processing and utilization / L.A. Johnson, P.J. White, R. Galloway Eds. Urbana, Ill. : AOCS Press, 2015. P. 409-440. DOI: doi.org/10.1016/C2015-0-02416-9.

${ }^{40}$ Shibata M., Takayama K., Ujjie A., Yamada T., Abe J., Kitamura K.. Genetic relationship between lipid content and linolenic acid content in soybean seeds. Breed. Sci. 2008. V. 58 (4). P. 361-366. DOI: 10.1270/jsbbs.58.361.

${ }^{41}$ Hammond E.G., Johnson L.A., Su C., Wang T., White P. Soybean oil. Bailey's industrial oil and fat products : monograph / F. Shahidi ed. $6^{\text {th }}$ ed. V. 2. Cpt. 13. Hoboken, NJ : Wiley \& Sons Publ., 2005. P. 577-653. DOI: doi.org/10.1002/047167849X.bio041.

${ }^{42}$ Lee J.-D., Bilyeu K.D., Shannon J.G. Genetics and breeding for modified fatty acid profile in soybean seed oil. J. Crop Sci. Biotechnol. 2008. V. 10 (4). P. 201-210.

${ }^{43}$ Rahman S.M., Anai T., Kinoshita T., Arima S., Takagi Y. Three novel soybean germplasms with unique fatty acid composition using multiple mutant alleles. Breed. Sci. 2004. V. 54. P. 225-229. 
Таблиця 3

Жирнокислотний склад олії представників основних типів сої, виділених із генетичного різноманіття культури,

зосередженого в Україні

\begin{tabular}{|c|c|c|c|c|c|}
\hline \multirow{2}{*}{$\begin{array}{c}\text { Тип жирнокислотного } \\
\text { складу олії }\end{array}$} & \multicolumn{5}{|c|}{ Вміст гліцеридів жирних кислот, \% до суми } \\
\hline & C16:0 & C18:0 & C18:1 & C18:2 & C18:3 \\
\hline Звичайний & 11,7 & 5,0 & 25,3 & 50,0 & 7,6 \\
\hline $\begin{array}{c}3 \text { підвищеним вмістом } \\
\text { пальмітату }\end{array}$ & 16,8 & 4,8 & 23,3 & 46,3 & 6,4 \\
\hline $\begin{array}{c}\text { Зі зниженим вмістом } \\
\text { пальмітату }\end{array}$ & 9,8 & 4,9 & 26,9 & 50,6 & 7,6 \\
\hline $\begin{array}{c}3 \text { підвищеним вмістом } \\
\text { стеарату }\end{array}$ & 15,1 & 6,7 & 26,2 & 45,4 & 4,4 \\
\hline $\begin{array}{c}\text { Зі зниженим вмістом } \\
\text { стеарату }\end{array}$ & 13,0 & 2,8 & 22,7 & 52,2 & 6,3 \\
\hline $\begin{array}{c}3 \text { підвищеним вмістом } \\
\text { олеату }\end{array}$ & 14,1 & 4,0 & 39,0 & 36,8 & 4,0 \\
\hline $\begin{array}{c}\text { 3і зниженим вмістом } \\
\text { олеату }\end{array}$ & 12,8 & 3,0 & 15,7 & 58,3 & 10,2 \\
\hline $\begin{array}{c}3 \text { підвищеним вмістом } \\
\text { линолеату }\end{array}$ & 11,8 & 3,6 & 18,3 & 58,7 & 7,1 \\
\hline $\begin{array}{c}\text { Iз зниженим вмістом } \\
\text { линолеату }\end{array}$ & 13,7 & 4,8 & 33,9 & 39,7 & 5,9 \\
\hline $\begin{array}{c}3 \text { підвищеним вмістом } \\
\text { линоленату }\end{array}$ & 10,6 & 3,7 & 19,2 & 55,4 & 11,2 \\
\hline $\begin{array}{c}\text { Iз зниженим вмістом } \\
\text { линоленату }\end{array}$ & 13,9 & 5,6 & 34,8 & 37,6 & 3,4 \\
\hline
\end{tabular}

\section{4. Олійні культури родини Капустяних (Brassicaceae)}

Особливістю жирнокислотного складу олій всіх культур родини Капустяних традиційного типу $\epsilon$ дуже високий вміст гліцеридів ерукової кислоти. Відомо, що ця кислота викликає низку фізіологічних порушень в організмі людини, тому іiі харчове використання небажане ${ }^{44}$. 3 іншого боку, олії з високим вмістом гліцеридів ерукової кислоти $\epsilon$ дуже цінною промисловою сировиною, яка використовується, зокрема, для виготовлення біопалив i біорозкладаваних термопластиків ${ }^{45}$, тому й підвищення, й зниження

44 Przybylski R., Mag T., Eskin N.A.M., McDonald B.E. Canola oil. Bailey's industrial oil and fat products : monograph / F. Shahidi Ed., $6^{\text {th }}$ ed. V. 2. Cpt. 2. Hoboken, NJ : Wiley \& Sons Publ., 2005. P. 61-121. DOI: doi.org/10.1002/047167849X.bio004.

${ }^{45}$ Sanyal A., Pinochet X., Merrien A., Laustriat M., Decocq G., Fine F. Erucic acid rapeseed: 1. Prospects of improvements. Oilseeds \& Fats Crops Lipids. 2015. V. 22 (3). D. 303. DOI: $10.1051 / \mathrm{ocl} / 2015011$. 
вмісту ерукової кислоти в оліях можуть розглядатися як незалежні напрями генетичного поліпшення олійних культур родини Капустяних.

Зниження вмісту ерукової кислоти у культур родини Капустяних супроводжується підвищенням вмісту олеату до $80 \% 46$.

Генетичний аналіз показав, що високий вміст олеату у ріпаку контролюється двома мутантними локусами, один з яких експресивний тільки в насінні й еквівалентний $f a d 2$, тоді як інший проявляє ефект також у листі та корені й регулює активність ферменту, відмінного від десатурази олеїнової кислоти ${ }^{47}$. Ці локуси діють аддитивно, а їх ефект за вмістом олеату значно більш суттєвий, ніж ефект полігенних комплексів.

Однак тільки підвищення вмісту олеату недостатньо для забезпечення високої якості олій капустяних культур, бо вони також містять значні кількості гліцеридів линоленової кислоти, тому на увагу заслуговує повідомлення про ідентифікацію мутантів, що поєднують у межах одного генотипу мутації типу $\mathrm{fad}-2$ i $\mathrm{fad}-3^{48}$.

На Україні зосереджено досить широке генетичне різноманіття олійних культур родини Капустяних, результати оцінки якого наведено в табл. 4.

\section{ВИСНОВКИ}

Отримані результати свідчать про широку мінливість основних олійних культур України за жирнокислотним складом олії, яка створює надійну основу для генетичного підвищення якості олії. При цьому культури, що належать до різних ботанічних таксонів, проявляють схожий тип мінливості жирнокислотного складу, який дає змогу припускати наявність у різних олійних культур схожих систем генетичної регуляції жирнокислотного складу.

${ }^{46}$ Rücker B., Röbbelen G. Mutants of Brassica napus with altered seed lipid fatty acid composition. Physiology, biochemistry and molecular biology of plant lipids I J.P. Wiiliams, M.U. Khan, N.W. Lem Eds. Dordrecht : Springer, 1997. P. 316-318. DOI: doi.org/10.1007/978-94-017-2662-7_100.

${ }^{47}$ Shierholt A., Rucker B., Becker H.C. Inheritance of high oleic acid mutations in winter oilseed rape (Brassica napus L.). Crop Sci. 2001. V. 41 (5). P. 1444-1449. DOI: doi.org/10.2135/cropsci2001.4151444x.

${ }^{48}$ Spasibionek S., Mikołajczyk K., Cwie-Kupczyńska H., Piętka T., Krotka K., Matuszczak M., Nowakowska J., Michalski K., Bartkowiak-Broda I. Marker assisted selection of new high oleic and low linolenic winter oilseed rape (Brassica napus L.) inbred lines revealing good agricultural value. PLoS One. V. 15 (6). e0233959. DOI: doi.org/10.1371/journal.pone.0233959. 
Таблиця 4

Генетичне різноманіття олійних культур родини Капустяних за жирнокислотним складом олії, зосереджене в Україні

\begin{tabular}{|c|c|c|c|c|c|c|}
\hline Типи олій & \multicolumn{6}{|c|}{ Вміст гліцеридів жирних кислот, \% до суми } \\
\hline & C 16:0 & C 18:0 & C 18:1 & C 18:2 & C $18: 3$ & C 22:1 \\
\hline \multicolumn{7}{|c|}{ Ріпак озимий (Brassica napus var.oleifera f.biennis) } \\
\hline Олеїновий & 3,7 & 2,0 & 72,0 & 12,7 & 6,9 & сліди \\
\hline Еруковий & 2,7 & 0,8 & 13,8 & 12,3 & 7,7 & 52,7 \\
\hline \multicolumn{7}{|c|}{ Ріпак ярий (Brassica napus var.oleifera f.annиa) } \\
\hline Олеїновий & 5,4 & 1,7 & 68,5 & 17,9 & 6,1 & 0,2 \\
\hline Еруковий & 4,9 & 1,4 & 15,1 & 15,5 & 9,3 & 51,4 \\
\hline \multicolumn{7}{|c|}{ Суріпиця яра (Brassica campestris L.) } \\
\hline Олеїновий & 4,5 & 1,5 & 65,1 & 20,5 & 8,1 & 0,1 \\
\hline Еруковий & 3,3 & 1,3 & 16,3 & 15,9 & 15,6 & 47,4 \\
\hline \multicolumn{7}{|c|}{ Гірчиця біла (Sinapis alba L.) } \\
\hline Олеїновий & 4,5 & 2,1 & 34,0 & 36,1 & 17,6 & 2,7 \\
\hline Еруковий & 2,5 & 0,7 & 14,4 & 9,5 & 12,8 & 52,9 \\
\hline \multicolumn{7}{|c|}{ Гірчиця сарептська (Brassica juncea L.) } \\
\hline Олеїновий & 4,0 & 1,7 & 42,1 & 32,8 & 14,7 & 2,2 \\
\hline Еруковий & 2,6 & 0,8 & 7,1 & 17,4 & 13,1 & 49,6 \\
\hline
\end{tabular}

\section{АНОТАЦІЯ}

Проведено узагальнення літературних даних із проблеми генетичної регуляції жирнокислотного складу олійних культур і результатів власних досліджень генетичного різноманіття основних олійних культур України за цією ознакою. Встановлено широкий розмах генотипової мінливості за вмістом гліцеридів насичених, мононенасичених і ненасичених кислот у кукурудзи, соняшнику, сої, ріпаку, гірчиці та суріпиці, показано паралелізм його мінливості у олійних культур, що належать до різних ботанічних таксонів.

\section{ЛITЕРАТУРА}

1. Industrial uses of vegetable oils : monograph / S.Z. Erhan Ed. Champaign, Ill. : AOCS Publ., 2005. 184 p. DOI: doi.org/10.4324/9781003040248.

2. Mielke T. World markets of vegetable oils: status and prospects. Encyclopedia of sustainable science and technology series / R.A. Mayer Ed. New-York : Springer Sci., 2017. P. 261-298. DOI: doi.org/10.1007/978-14939-7813-7_989.

3. Hammond E.W. Vegetable oils: types and properties. Encyclopedia of food sciences and nutrition / B. Caballero, P. Finglas, F. Toldra Eds. $2^{\text {nd }}$ ed. San-Diego ; London : Acad. Press, 2003. P. 5916-5921. DOI: 10.1016/B0-12-227055-X/01227-X. 
4. Oliveira L.E., Da Silva M.L.C.P. Comparative study of caloric value of rapeseed, soybean, jatropha and crambe biodiesel. Ren. Energ. Pow. Qual. J. 2013. V. 1 (11). P. 689-682. DOI: doi.org/ 10.24084/repqj11.411.

5. McClements D.J., Decker E.A. Lipids. Fennema's food chemistry: monograph / S. Damodaran, K.L. Parkin, O.R. Fennema Eds. $4^{\text {th }}$ ed. Cpt. 5. Boca-Raton, Fl. : CRC Press, 2008. P. 155-216. DOI: 10.1016/j.foodchem.2012.04.040.

6. O'Brien R.D. Fats and oils: formulating and processing for applications : monograph. 3d ed. Boca-Raton, Fl. : CRC Press, 2008. 680 p. DOI: doi.org/10.1201/9781420061673.

7. Arvanitoyannis I.S., Varzakas T.H., Kiokias S. Labropoulos A.E. Lipids, fats and oils. Advances in food biochemistry : monograph / F. Vildiz Ed. Chpt. 5. Boca Raton, Fl. : CRC Press, 2010. P. 131-202. DOI: doi.org/10.1201/9781420007695.

8. Kumara A., Sharmaa A., Upadhyayab K.C. Vegetable Oil: nutritional and industrial perspective. Current Genomics. 2016. Is. 17. P. 230-240. DOI: $10.2174 / 1389202917666160202220107$.

9. Valenzuela Baez R., Valenzuela Baez A. Overview about lipid structure. Lipid metabolism : monograph / R. Valenzuela ed. Chpt. 1. Rijeka, Croatia : InTech, 2013. P. 3-20. DOI: 10.5772/52306.

10. Rustan A.C., Drevon C.A. Fatty Acids: structures and properties. Encyclopedia of Life Sciences. Chichester : John Wiley \& Sons, Ltd., Chichester, 2005, V. 7. P. 1-7. DOI: doi.org/10.1038/npg.els.0003894.

11. Cnothe G., Dunn R.O. A comprehensive evaluation of the melting points of fatty acids and esters determined by differential scanning calorimetry. J. Amer. Oil Chem. Soc. 2009. V. 86 (9). P. 843-856. DOI: 10.1007/s11746-009-1423-2.

12. Devi A., Khatkar B.S. Physicochemical, rheological and functional properties of fats and oils in relation to cookie quality: a review. J. Food Sci. Technol. 2016. V. 53 (10). P. 3633-3641. DOI: 10.1007/ s13197-016-2355-0.

13. White P. Fatty acids of oilseeds vegetable oils. Fatty acids in foods and their health implications : monograph / C.K. Chow ed. 3d Ed. Cpt. 10. Boca-Raton, Fl. : CRC Press, 2007. P. 227-262. DOI: doi.org/10.1201/9781420006902.ch.10.

14. Ratledge C. Microbial Production of Vitamin F and other polyunsaturated fatty acids. Industrial biotechnology of vitamins, biopigments and antioxidants : monograph / E.J. Vandamme, J.L. Revuelta Eds. $3^{\text {th }}$ ed. Chpt. 11. Weinheim : Wiley VCH, 2016. P. 287-320. DOI: 10.1002/9783527681754.ch11.

15. Niki E., Yoshida Y., Saito Y., Noguchi N. Lipid peroxidation: mechanisms, inhibition, and biological effects. Biochim. Biophys. Res. Commun. 2005. V. 338 (1). P. 668-676. DOI: 10.1016/j.bbrc.2005.08.072. 
16. Vanhercke T., Wood C.C., Stymne S., Singh S.P., Green A.G. Metabolic engineering of plant oils and waxes for use as industrial feedstocks. Plant Biotechnol. J. 2013. V. 11 (2). P. 197-210. DOI: 10.1111/pbi.12023.

17. Vollmann J., Raican I. Oil crop breeding and genetics. Oil crops : monograph / J. Volmann, I. Raican Eds. Chpt. 1. Dordrecht ; Heidelberg ; London ; New-York : Springer Sci., 2009. P. 1-30. DOI: 10.1007/978-0387-77594-4_1.

18. Aguirrezabal L., Martre P., Pereyra-Irujo G., Izquerdo N., Allard V. Management and breeding strategies for the improvement of grain and oil quality. Crop physiology: application for genetic improvement and agronomy : monograph / V.O. Sardas, D.F. Calderini Eds. Chpt. 16. Burlington, MA : Elsevier-Academic Press, 2009. P. 387-421. DOI: doi.org/10.1016/B978-0-12-374431-9.00016-5.

19. Dyer J.M., Mullen R.T. Development and potential of genetically engineered oilseeds Seed Science Research. 2005. V. 15 (4). P. 255-267. DOI: $10.1079 /$ SSR2005216.

20. Vritten P., Hu Z., Muchinsky M.-A., Rowland G., Qui X. Two FAD3 desaturase genes control the level of linolenic acid in flax seed. Plant Physiol. 2005. V. 139 (1). P. 79-87. DOI: 10.1104/pp.105.064451.

21. Dar A.A., Choudhury A.R., Kancharla P.K., Arumugam N. The FAD2 gene in plants: occurrence, regulation and role. Front. Plant Sci. 2017. Is. 8. Article 1789. 16 p. DOI: 10.3389/fpls.2017.01789.

22. Pandjabi P., Yadava S.K., Kumar N., Bangkim R., Ramchiary N. Breeding Brassica juncea and B.rapa for sustainable oilseed production in the changing climate : progress and prospects. Genomic designing of climate - smart oilseed crops : monograph / C. Kole Ed. Chpt. 6. Cham, SWI. : Springer, 2019. P. 275-369. DOI: 10.1007/978-3-319-93536-2_6.

23. Murphy D.J. Using modern plant breeding to improve the nutritional and technological qualities of oil crops. Oiseeds \& Fats Crops Lipids. 2014. V. 21 (6). D. 607. DOI: 10.1051/ocl/2014038.

24. Haun W., Coffman A., Clasen B.M., Demorest Z.L., Lowy A., Ray E., Retterath A., Stoddart T., Juilletat A., Cedrone F., Mathis L., Voytas D.F., Zhang F. Improved soybean oil quality by targeted mutagenesis of the fatty acid desaturase 2 gene family. Plant Biotechnol. J. 2014. V. 12 (7). P. 934-940. DOI: 10.1111/pbi.12201.

25. Gavrilova V., Shelenga T., Porokhovinova E., Dubovskaya A., Kon'kova N., Grigoryev S., Podolnaya L., Konarev A., Yakusheva T., Kishlyan N., Pavlov A., Brutch N. The diversity of fatty acid composition in traditional and rare oil crops cultivated in Russia. Bio. Comm. 2020. № 65 (1). P. 68-81. DOI: doi.org/10.21638/spbu03.2020.106. 
26. Yang X., Guo Y., Yan J., Zhang J., Song T., Rocheford T., Li J.-S. Major and minor QTL and epistasis contribute to fatty acid compositions and oil concentration in high-oil maize. Theor. Appl. Genet. 2010. V. 120 (3). P. 665-678. DOI: 10.1007/s00122-009-1184-1.

27. Прохорова М.И. Методы биохимических исследований. Ленинград : Химия, 1982.272 с.

28. Wang T, White P. Lipids of the kernel. Corn: chemistry and technology : monography / S.O. Serna-Saldivar Ed. 3th ed. Chpt. 13. Duxford, UK : Elsevier-Woodhead Publ., 2019. P. 337-368. DOI: doi.org/10.1016/b978-0-12-811971-6.00013-9.

29. Singh N., Vasudev S., Yadava D.K., Chaudhary D.P., Prabhu K.V. Oil improvement in maize : potential and prospects. Maize: nutrition dynamics and novel uses : monography / D.P. Chaudhary, S. Kumar, S. Langyan Eds. Chpt. 6. Heidelberg ; New-York ; Dordrecht ; London : Springer, 2014. P. 77-82. DOI: 10.1007/978-81-322-1623-0_6.

30. Boyer C.D., Hannah L.C. Kernel mutants of corn. Specialty corns : monograph / A.R. Hallauer Ed. Boca Raton, Fl. : CRC Press, 2001. P. 8-38. DOI: https://doi.org/10.1201/9781420038569.

31. Mikkilineni V., Rocheford T.R. Sequence variation and genomic organization of fatty acid desaturase-2 (fad2) and fatty acid desaturase-6 (fad6) cDNAs in maize. Theor. Appl. Genet. 2003. V. 106 (7). P. 13261332. DOI: $10.1007 / \mathrm{s} 00122-003-1190-7$.

32. Belo A., Zheng P., Luck S., Shen B., Meyer D.J., Li B., Tingey S., Rafalski A. Whole genome scan detects an allelic variant of fad 2 associated with increased oleic acid levels in maize. Mol. Genet. Genom. 2008. № 279 (1). P. 1-10. DOI: 10.1007/s00438-007-0289-y.

33. Wassom J.J., Mikkilineni V., Bohn M.O., Rocheford T.R. QTL for fatty acid composition of maize kernel oil in Illinois High Oil $\times$ B73 backcross-derived lines. Crop Sci. 2008. № 48 (1). P. 69-78. DOI: doi.org/10.2135/cropsci2007.040208.

34. Coe E.H., Schaeffer M.L. Genetic, physical, maps, and database resources for maize. Maydica. 2005. № 50 (3). P. 285-303. DOI: doi.org/10.1371/journal.pgen.0030123.

35. White P.J., Pollak L.M., Duvick S. Improving the fatty acid composition of corn oil by using germplasm introgression. Lipid Technol. 2007. V. 19 (2). P. 35-38. DOI: doi.org/10.1002/lite.200600009.

36. Scoric D., Seiler G., Liu Z., Jan C.-C., Miller J.F., Charlet L.D. Sunflower genetics and breeding. International monography. Novi Sad : Serbian Acad. Sci.Art., 2012. 520 p. DOI: 10.3390/genes9110528.

37. Ferfuia C., Vannozzi G.P. Maternal effect on seed fatty acid composition in a reciprocal cross of high oleic sunflower (Helianthus 
annuus L.). Euphytica. 2015. V. 205 (2). P. 325-336. DOI: 10.1007/s10681015-1378-3.

38. Perez-Vich B., Fernandez J., Garces R., Fernandez-Martinez J.M. Inheritance of high palmitic acid content in the seed oil of sunflower mutant CAS-5. Theor. Appl. Genet. 1999. V. 98 (3). P. 496-501. DOI: 10.1007/s001220051097.

39. Perez-Vich B., Garces R., Fernandez-Martinez J.M. Genetic control of high stearic acid content in the seed oil of sunflower mutant CAS-3. Theor. Appl. Genet. 1999. V. 99 (3-4). P. 663-669. DOI: doi.org/10.1007/s001220051282.

40. Salas J.J., Martinez-Force E., Garces R. Biochemical characterization of a high-palmitoleic acid Helianthus annuus mutant. Plant Physiol. Biochem. 2004. V. 42 (5). P. 373-381. DOI: 10.1016/j.plaphy.2004.03.001.

41. Кириченко В.В., Тимчук С.М., Брагін О.М. Генетичне різноманіття ліній соняшнику за жирнокислотним складом олії. Генетичні ресурси рослин. 2007. № 4. С. 131-139.

42. O'Brien R.D. Soybean oil modification. Soybeans : chemistry, production, procesing and utilization / L.A. Johnson, P.J. White, R. Galloway Eds. Urbana, Ill. : AOCS Press, 2015. P. 409-440. DOI: doi.org/10.1016/C2015-0-02416-9.

43. Shibata M., Takayama K., Ujjie A., Yamada T., Abe J., Kitamura K. Genetic relationship between lipid content and linolenic acid content in soybean seeds. Breed. Sci. 2008. V. 58 (4). P. 361-366. DOI: $10.1270 /$ jsbbs. 58.361 .

44. Hammond E.G., Johnson L.A., Su C., Wang T., White P. Soybean oil. Bailey's industrial oil and fat products : monograph / F. Shahidi Ed. $6^{\text {th }}$ ed. V. 2. Cpt. 13. Hoboken, NJ : Wiley \& Sons Publ., 2005. P. 577-653. DOI: doi.org/10.1002/047167849X.bio041.

45. Lee J.-D., Bilyeu K.D., Shannon J.G. Genetics and breeding for modified fatty acid profile in soybean seed oil. J. Crop Sci. Biotechnol. 2008. V. 10 (4). P. 201-210.

46. Rahman S.M., Anai T., Kinoshita T., Arima S., Takagi Y. Three novel soybean germplasms with unique fatty acid composition using multiple mutant alleles. Breed. Sci. 2004. V. 54. P. 225-229.

47. Przybylski R., Mag T., Eskin N.A.M., McDonald B.E. Canola oil. Bailey's industrial oil and fat products : monograph / F. Shahidi Ed. $6^{\text {th }}$ ed. V. 2. Cpt. 2. Hoboken, NJ : Wiley \& Sons Publ., 2005. P. 61-121. DOI: doi.org/10.1002/047167849X.bio004.

48. Sanyal A., Pinochet X., Merrien A., Laustriat M., Decocq G., Fine F. Erucic acid rapeseed: 1. Prospects of improvements. Oilseeds \& Fats Crops Lipids. 2015. V. 22 (3). D. 303. DOI: 10.1051/ocl/2015011. 
49. Rücker B., Röbbelen G. Mutants of Brassica napus with altered seed lipid fatty acid composition. Physiology, biochemistry and molecular biology of plant lipids / J.P. Wiiliams, M.U. Khan, N.W. Lem Eds. Dordrecht : Springer, 1997. P. 316-318. DOI: doi.org/10.1007/978-94-0172662-7_100.

50. Shierholt A., Rucker B., Becker H.C. Inheritance of high oleic acid mutations in winter oilseed rape (Brassica napus L.). Crop. Sci. 2001. V. 41 (5). P. 1444-1449. DOI: doi.org/10.2135/cropsci2001.4151444x.

51. Spasibionek S., Mikołajczyk K., Cwiek- Kupczyńska H., Piętka T., Krotka K., Matuszczak M., Nowakowska J., Michalski K. , BartkowiakBroda I. Marker assisted selection of new high oleic and low linolenic winter oilseed rape (Brassica napus L.) inbred lines revealing good agricultural value. PLoS One. 2020. V. 15 (6). e0233959. DOI: doi.org/ 10.1371/journal.pone.0233959.

\section{Information about the authors:} Tymchuk D. S.,

Candidate of Biological Sciences, Associate Professor at the Department of Social, Humanitarian and Biomedical Disciplines Kharkiv Institute of Medicine and Biomedical Sciences of Kyiv Medical University 11, Sadova str., Kharkiv, 61002, Ukraine

Kharchenko L. Ya., Researcher at the Laboratory of Legumes, Cereals and Maize Ustymivska Research Station of Plant Growing 15, Akademika Vavilova str., Ustymivka village, Poltava region, 39074, Ukraine 